(C) 2019 Lokshyna. This article is distributed under the terms of CC Attribution-Share Alike 4.0 International as described at https://creativecommons.org/ licenses/ by-sa/4.0

UDC: $37.013 .74: 005.745](100)$

\title{
«COMPARATIVE AND INTERNATIONAL EDUCATION» CONFERENCE: TEN YEARS IN THE EDUCATIONAL SPACE. PROFILE OF THE PARTICIPANTS
}

\author{
Olena Lokshyna \\ Doctor of Pedagogical Sciences, Professor, \\ Head of the Comparative Education Department, \\ Institute of Pedagogy of the National Academy of Educational Sciences of Ukraine, \\ Kyiv, Ukraine \\ https://orcid.org/0000-0001-5097-0171,e-mail: olena.lokshyna@gmail.com
}

The article is devoted to the analysis of the input of the international conference "The Comparative and International Education» that is being conducted by the Department of the Comparative Education of the Institute of Pedagogy of the National Academy of Educational Science of Ukraine since 2010. Having analysed the aspect of participation the author studies the number and profile of the individual participants, number and profile of the institutions as well as the number of the regions of Ukraine/countries that participated in the conference. Based on the data obtained, the author concludes on the efficiency of the conference in terms of the professional growth of the participants, the formation of comparative education regionnal communities and of the comparative education community of practice at the Ukrainian level. Based on the indices of participation at the individual level the author concluded that the conference has attracted considerable interest of a large number of researchers. The growth of such interest from year to year is evidenced by the data on the gradual increase in the number of the participants. The author noted that the young researchers/faculty from higher education/research institutions constituted the majority of the participants. The conference has facilitated the formation of a generation of comparative educators who have enriched methodological approaches to CE research, initiated by the oldest CE unit in Ukraine - the Department of Comparative Education of the Institute of Pedagogy of the NAES of Ukraine (established in 1971). The support in the formation of regional communities of comparative education is another input of the "The Comparative and International Education" conference. Attendance of the conference by the representatives from different institutions of a region was the common practice. The author makes conclusion that the integration of the comparative educators from all over Ukraine is a substantial accomplishment of the conference. In fact, the All-Ukrainian Comparative Educators' 
Community of Practice was formed. Under the auspices of the "The Comparative and International Education» conference - the only professional conference on comparative education in Ukraine - the comparative educators gathered annually to discuss the experiences, challenges, and perspectives of comparative education in Ukraine and worldwide, gain new knowledge and advanced ideas.

Key words: The "Comparative and International Education" conference, Department of Comparative Education of the Institute of Pedagogy of the National Academy of Education Sciences of Ukraine, participation, profile.

Статтю присвячено розгляду внеску міжнародної конференції «Порівняльа педагогіка і міжнародна освіта», яку, починаючи з 2010 року, щорічно проводить відділ порівняльної педагогіки Інституту педагогіки Національної академї педагогічних наук Украӥни, у розвиток порівнялної педагогіки $b$ Украйні. Розглядаючи аспект участі у конференції, автор проводить аналіз кількості та профілю індивідуальних учасників, кількості та профілю учасників-інституцій, та кількості регіонів Украӥни і крайн, які взяли участь у конференції протягом десяти років ї̈ існуВання (2010-2019 роки). Базуючись на отриманих даних, автор робить висновок про ефективність конференції, яка сприяла професійному зростанню учасників, формуВанню регіональних осередків порівняльної педагогіки, формуванню спільноти практикіВ - дослідників порівняльної педагогіки всеукраїнсъкого рівня.

Ключові слова: міжнародна конференція «Порівняльа педагогіка і міжнародна освіта», Відділ порівняльої педагогіки Інституту педагогіки НАПН Украйни, участь, профіль.

Introduction. The «Comparative and International Education» (C\&IE) conference is held annually by the Department of Comparative Education of the Institute of Pedagogy of the National Academy of Education Sciences (NAES) of Ukraine since 2010. The idea of such an event has emerged in the Department of Comparative Education as a response to the need for communication of the comparative education (CE) researchers of the NAES institutions. Initially the purpose of the event was viewed from the standpoint of synchronisation of the CE methodology at the NAES level as well as of sharing experience between the NAES researchers in the area. Considering it as a chamber event, it was named a "Comparative Education» seminar. However, starting from the first year, the seminar went beyond the NAES borders. It became the nationwide scale event gathering besides the NAES scholars the educators from other institutions. This proved both the timeliness of the event and the optimality of its format. In 2017, the transformation of its concept due to the new demands of the academic community and the Ukrainian education realities led to the change of its status - the seminar was transformed into an international conference named «Comparative and International Education». The change of its purpose and format resulted in an increase of the number of participants and types of participating institutions. 
In 2019, C\&IE conference celebrated its $10^{\text {th }}$ anniversary. Anniversaries always invite to generalization. Ten years is a term that brings to comprehending the C\&IE conference efficiency. In the article, its efficiency is examined in terms of participation. In particular, the participation is analysed at various levels, i.e., individual, institutional, geographical. The profiles of individual participants, participating institutions and regions of Ukraine/countries are presented in the article.

Literature Review. In 2015, the C\&IE conference phenomenon was used by the author of this article to analyse the areas of the studies of the comparative educators in Ukraine. The foregoing analysis is presented in the opening remarks of the book of abstracts of the C\&IE conference «Comparative Education - 2015: the movement to multidimensionality. On the example of studies presented in the framework of the seminar «Comparative Education» during 2010-2015». The author hypothesized that the abstracts of the CE scholars, presented in the conference books, reflect, in a certain way, the directions of the national CE scholars' studies. Based on it, the author writes about the widening the CE research areas and advancing its methodology during 2010-2015 (Lokshyna, 2015). Information about the $10^{\text {th }}$ anniversary of the C\&IE conference is presented in "Comparative \& International Education» conference - ten years in the educational space (Lokshyna, 2019).

Methodology. The C\&IE conference programmes (years 2010, 2011, 2012, 2013, 2014, 2015, 2016, 2017, 2018, and 2019) were analysed under the following rubrics: a) individual level: number and profile of the individual participants; b) institutional level: number and types of institutions participating in the conference; c) geographical level: number and names of the regions of Ukraine participating in the conference; countries that have participated in the conference.

Hence, answers to the following questions were sought: 1) What is the profile of individual participants? 2) What is the profile of institutions that have participated in the conference? 3) What regions of Ukraine/countries participated in the conference? 4) Can the C\&IE conference be regarded as efficient based on the data on participation?

Results and Discussion. Data on the number of the participants by year show a steady tendency of increasing interest in the C\&IE conference (Fig. 1).

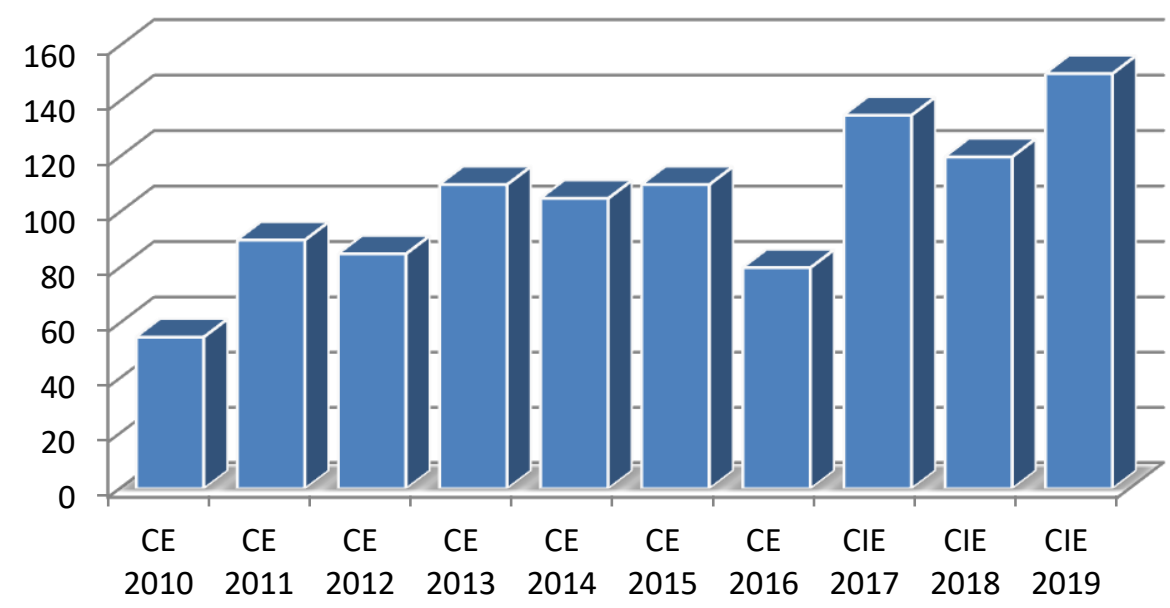

Fig. 1. Number of the C\&IE conference participants by years 
53 participants took part in the first year the C\&IE conference in 2010. In 2013, the number of the participants exceeded 100 persons and reached the level of 150 in 2019. A total of 1033 researchers joined the conference discussion on challenges and achievements of CE in a decade. The analysis of the number of participants by year shows their steady growth over the first 6 years. The reduction in the attendance in 2016 was overcome in 2017 after the transformation of the format of the C\&IE from the all-Ukrainian seminar to an international conference.

The constant participation of many participants over the years is the feature of the conference. In fact, more than half of them attended C\&IE conference more than five times and more than 20 researchers participated in it each year for 10 years. Such continued participation can be regarded as a sign of the conference popularity among scholars.

Analysing the phenomenon of C\&IE at the institutional level, we can say that the representatives of 110 institutions (scientific institutions, universities, secondary education institutions, etc.) have taken part in the event for 10 years.

It should be noted that the representatives of the CE units of the NAES of Ukraine form the core of C\&IE conference. These are the Department of the Comparative Education of the Institute of Pedagogy of the NAES of Ukraine; Department of Foreign Systems of Pedagogical and Adult Education of the Ivan Ziaziun Institute of Pedagogical and Adult Education of the NAES of Ukraine; Department of Comparative Studies for Information and Education Innovations of the Institute of Information Technologies and Learning Tools of the NAES of Ukraine; and Laboratory of Foreign Systems of Vocational Education and Training of the Institute of Vocational Education and Training of the NAES of Ukraine. The Department of Giftedness Support and International Cooperation of the Institute of Gifted Child of the NAES of Ukraine also participated in the first years of the conference. Since its closure, the number of participants has decreased dramatically.

In addition to the above-mentioned units, the representatives of other institutions of the NAES of Ukraine participated in the conference as well. This testifies to a great attention paid by the NAES to CE, to understanding its mission in the reforming of the national education (Table 1).

Table 1

\section{Distribution of the C\&IE conference participants from the NAES of Ukraine by years}

\begin{tabular}{|c|c|c|c|c|c|c|c|c|c|c|}
\hline $\begin{array}{l}\text { Institutions of the } \\
\text { NAES of Ukraine }\end{array}$ & $\begin{array}{c}C E \\
2010\end{array}$ & $\begin{array}{c}C E \\
2011\end{array}$ & $\begin{array}{c}C E \\
2012\end{array}$ & $\begin{array}{c}C E \\
2013\end{array}$ & $\begin{array}{c}C E \\
2014\end{array}$ & $\begin{array}{c}C E \\
2015\end{array}$ & $\begin{array}{c}C E \\
2016\end{array}$ & $\begin{array}{c}C I E \\
2017\end{array}$ & $\begin{array}{l}C I E \\
2018\end{array}$ & $\begin{array}{c}\text { CIE } \\
2019\end{array}$ \\
\hline $\begin{array}{l}\text { Institute of } \\
\text { Pedagogy }\end{array}$ & 17 & 12 & 13 & 13 & 10 & 13 & 10 & 23 & 32 & 50 \\
\hline $\begin{array}{l}\text { Ivan Ziaziun } \\
\text { Institute of } \\
\text { Pedagogical and } \\
\text { Adult Education }\end{array}$ & 8 & 10 & 9 & 13 & 7 & 8 & 5 & 6 & 2 & 2 \\
\hline $\begin{array}{l}\text { Institute of Gifted } \\
\text { Child }\end{array}$ & 4 & 1 & 8 & 11 & 4 & 5 & - & - & - & 4 \\
\hline
\end{tabular}


Continuation table 1

\begin{tabular}{|l|c|c|c|c|c|c|c|c|c|c|}
\hline $\begin{array}{l}\text { Institute of } \\
\text { Information } \\
\begin{array}{l}\text { Technologies and } \\
\text { Learning Tools }\end{array}\end{array}$ & 5 & 8 & 7 & 10 & 9 & 8 & 4 & 5 & 6 & 1 \\
\hline $\begin{array}{l}\text { Institute of Voca- } \\
\text { tional Education } \\
\text { and Training }\end{array}$ & - & - & - & 2 & 1 & 2 & 6 & 6 & 3 & 3 \\
\hline $\begin{array}{l}\text { State Higher Edu- } \\
\text { cational Institu- } \\
\text { tion «University of } \\
\begin{array}{l}\text { Educational } \\
\text { Management» }\end{array}\end{array}$ & 2 & 3 & 7 & 2 & 2 & 1 & 1 & - & - & - \\
\hline Presidium & - & 1 & 2 & 1 & - & 1 & 1 & - & 1 & 1 \\
\hline $\begin{array}{l}\text { Institute of } \\
\text { Problems on } \\
\text { Education }\end{array}$ & 1 & - & - & - & - & - & 1 & - & - & 1 \\
\hline $\begin{array}{l}\text { Institute of Higher } \\
\text { Education }\end{array}$ & - & - & - & - & - & - & - & - & 1 & - \\
\hline $\begin{array}{l}\text { G. S. Kostyuk } \\
\text { Institute of } \\
\text { Psychology }\end{array}$ & - & - & - & - & - & - & - & - & - & 1 \\
\hline
\end{tabular}

As can be seen from the Table 1 the scholars of the Institute of Pedagogy of the NAES of Ukraine constituted the largest part of the C\&IE participants during the whole 10-year period, i.e. 293 participants. Primarily these are the scholars of the Department of the Comparative Education of the Institute of Pedagogy of the NAES of Ukraine - the C\&IE conference organizer.

The given data show the dependence of the number of participants on the format of the event. During the years of the C\&IE in the format of the all-Ukrainian seminar, the number of the participants from the Institute of Pedagogy consistently amounted to 10-15 people. Since the event transformation into an international conference in 2017, there is a gradual increase of the number to 50 participants. Such growth can be explained by the fact that during the years of the event in the format of a seminar its key purpose was the development/discussion of the methodology of CE. It accordingly united first the CE researchers - scholars and post-graduates of the Department of Comparative Education. Since the seminar was transformed into an international conference, the purpose of the event has been broadened. In parallel with the further development of the CE methodology, the discussion of prospective foreign experience and ways of its implementation into the national education has become important. Under these conditions, the target audience expanded accordingly - scholars from other departments of the Institute of Pedagogy of the NAES of Ukraine joined the conference. 
It is necessary to emphasize the conditionality of the given indicators while analysing the number of participants from other institutions of the NAES of Ukraine. The presences of a specialized unit in the structure of an institution in which comparative studies are carried out are to be considered. As noted above, there are currently four units in NAES and they accordingly have delegated the largest number of the participants among all NAES institutions.

In 2012, the Department of Foreign Systems of Pedagogical and Adult Education of the Ivan Ziaziun Institute of Pedagogical and Adult Education of the NAES of Ukraine in cooperation with Khmelnytskyi National University (the Centre of Comparative Professional Education) launched an international scientific and methodological seminar «Development of Comparative Professional Education in the Context of Globalization and Integration Processes». It explains the decrease of the number of the participants from this unit in the C\&IE conference (as indicated in Table 1).

The institutions of higher education - multi-sectoral and sectoral universities, academies, institutes constitute lion's share of the C\&IE participants. Firstly, it should be noted a large representation of the national universities. These are Ivan Franko National University of Lviv, Kamianets-Podilsky Ivan Ohienko National University, Khmelnytskyi National University, Kremenchuk Mykhailo Ostrohradskyi National University, Kryvyi Rih National University, Luhansk Taras Shevchenko National University, Odesa I. Mechnikov National University, Taras Shevchenko National University of Kyiv, Vasyl Stefanyk Precarpathian National University, Uzhgorod National University.

The representatives of the following state universities attended the C\&IE conference: Kherson State University, Mariupol State University, Mukachevo State University, Nizhyn Mykola Gogol State University, Zhytomyr Ivan Franko State University, etc.

Participation of the sectoral universities was also sufficiently large. The following sectoral universities were the C\&IE participants: Cherkasy State Technological University, Danylo Halytsky Lviv National Medical University, Donetsk National Medical University, I. Horbachevsky Ternopil National Medical University, Ivan Kozhedub Kharkiv National University of Air Force, Ivano Frankivsk National Technical University of Oil and Gas, Kiev National Linguistic University, Lviv Polytechnic National University, National Aviation University, National Technical University of Ukraine «Igor Sikorsky Kyiv Polytechnic Institute», National Transport University, National University of Pharmacy (Kharkiv), National University of Water Management and Nature Resources Use (Rivne), Podilsky State Agrarian Technical University, Rivne State University of Humanities, Sumy National Agrarian University, Ternopil National Economic University, Vadym Hetman Kyiv National Economic University.

The most active universities (with 10 or more participants in the conference) are listed in the Table 2. 
Table 2

The universities - the most active C\&IE conference participants by years

\begin{tabular}{|l|c|c|c|c|c|c|c|c|c|c|}
\hline \multicolumn{1}{|c|}{ Institution } & CE & CE & CE & CE & CE & CE & CE & CIE & CIE & CIE \\
2011 & 2012 & 2013 & 2014 & 2015 & 2016 & 2017 & 2018 & 2019 \\
\hline $\begin{array}{l}\text { I. Horbachevsky } \\
\text { Ternopil National } \\
\text { Medical University }\end{array}$ & - & - & 1 & - & 2 & 2 & 2 & 1 & 5 & 13 \\
\hline $\begin{array}{l}\text { Lviv Polytechnic } \\
\text { National } \\
\text { University }\end{array}$ & - & - & - & 3 & - & - & - & 7 & 5 & 1 \\
\hline $\begin{array}{l}\text { Ivan Franko } \\
\text { National Univer- } \\
\text { sity of Lviv }\end{array}$ & - & - & - & 1 & - & 9 & 1 & 2 & 2 & - \\
\hline $\begin{array}{l}\text { Vadym Hetman } \\
\text { Kyiv National } \\
\text { Economic } \\
\text { University }\end{array}$ & - & 1 & 1 & 1 & 4 & 1 & 1 & 3 & 1 & 1 \\
\hline $\begin{array}{l}\text { Ternopil National } \\
\text { Economic } \\
\text { University }\end{array}$ & - & - & 2 & 3 & 1 & 2 & 3 & 1 & 1 & 1 \\
\hline $\begin{array}{l}\text { National Technical } \\
\text { University of } \\
\text { Ukraine «Igor } \\
\text { Sikorsky Kyiv } \\
\text { Polytechnic } \\
\text { Institute» }\end{array}$ & - & - & - & - & - & 2 & 4 & 4 & 2 & - \\
\hline $\begin{array}{l}\text { Taras Shevchenko } \\
\text { National Univer- } \\
\text { sity of Kyiv }\end{array}$ & - & - & - & 1 & 3 & 2 & 1 & 1 & 1 & 1 \\
\hline $\begin{array}{l}\text { National Aviation } \\
\text { University }\end{array}$ & - & - & 2 & - & - & - & 2 & 3 & 1 & 2 \\
\hline $\begin{array}{l}\text { Borys Grinchenko } \\
\text { Kyiv University }\end{array}$ & - & - & - & - & - & 1 & 1 & 2 & 3 & 3 \\
\hline
\end{tabular}

The analysis shows that the faculty of foreign languages departments from the classical and sectoral universities is the core of the conference participants. Knowledge of foreign languages enables the faculty to carry out research in CE. It attests to the existence of CE centres/schools in these institutions.

Besides, there is a strong interest in participating in the conference by some higher education institutions throughout the ten-year period, although the number of participants was relatively small (table 3). 
Table 3

The higher education institutions - permanent C\&IE conference participants with a small number of attendants (by years)

\begin{tabular}{|l|c|c|c|c|c|c|c|c|c|c|}
\hline \multicolumn{1}{|c|}{ Institution } & CE & CE & CE & CE & CE & CE & CE & CIE & CIE & CIE \\
& 2010 & $\mathbf{2 0 1 1}$ & $\mathbf{2 0 1 2}$ & $\mathbf{2 0 1 3}$ & $\mathbf{2 0 1 4}$ & $\mathbf{2 0 1 5}$ & $\mathbf{2 0 1 6}$ & $\mathbf{2 0 1 7}$ & $\mathbf{2 0 1 8}$ & $\mathbf{2 0 1 9}$ \\
\hline $\begin{array}{l}\text { Sumy National } \\
\text { Agrarian University }\end{array}$ & - & - & - & 2 & 2 & 1 & 1 & 1 & 1 & 1 \\
\hline $\begin{array}{l}\text { Podilsky State } \\
\text { Agrarian Technical } \\
\text { University }\end{array}$ & - & 2 & 2 & 1 & 1 & 1 & 1 & 1 & - & - \\
\hline $\begin{array}{l}\text { Petro Konachevych- } \\
\text { Sahaidachny State } \\
\begin{array}{l}\text { Water Transport } \\
\text { Academy of Kyiv }\end{array}\end{array}$ & - & 1 & 3 & 1 & 1 & 1 & 1 & - & - & - \\
\hline $\begin{array}{l}\text { Berdyansk State } \\
\text { Pedagogical } \\
\text { University }\end{array}$ & - & - & 1 & 1 & 1 & 1 & 1 & 1 & - & - \\
\hline
\end{tabular}

Long-standing professional relations between the staff of the CE Department of the Institute of Pedagogy and the representatives of the mentioned universities explain such persistence in participation.

Undoubtedly, the pedagogical universities were the leaders among the participants from the higher education institutions. As a rule, $\mathrm{CE}$ has a prominent place in the curriculum of these universities, i.e., here CE courses are taught, CE textbooks are published. This explains great interest of the representatives of these universities in communication and the publication of their CE research findings. These are, first, the pedagogical universities-long-term partners of the Department of Comparative Education of the Institute of Pedagogy of the NAES of Ukraine (table 4).

Table 4

Distribution of the C\&IE conference participants from the pedagogical universities-partners of the of CE Department of the Institute of Pedagogy of the NAES of Ukraine by years

\begin{tabular}{|c|c|c|c|c|c|c|c|c|c|c|}
\hline Institution & $\begin{array}{c}C E \\
2010\end{array}$ & $\begin{array}{c}\text { CE } \\
2011\end{array}$ & $\begin{array}{c}\text { CE } \\
2012\end{array}$ & $\begin{array}{c}\text { CE } \\
2013\end{array}$ & $\begin{array}{c}\text { CE } \\
2014\end{array}$ & $\begin{array}{c}\text { CE } \\
2015\end{array}$ & $\begin{array}{c}C E \\
2016\end{array}$ & $\begin{array}{l}\text { CIE } \\
2017\end{array}$ & $\begin{array}{c}\text { CIE } \\
2018\end{array}$ & $\begin{array}{l}\text { CIE } \\
2019\end{array}$ \\
\hline $\begin{array}{l}\text { A. S. Makarenko } \\
\text { Sumy State } \\
\text { Pedagogical } \\
\text { University }\end{array}$ & 9 & 20 & 4 & 15 & 18 & 11 & 9 & 10 & 10 & 9 \\
\hline $\begin{array}{l}\text { Pavlo Tychyna } \\
\text { Uman State } \\
\text { Pedagogical } \\
\text { University }\end{array}$ & - & 7 & 9 & 8 & 8 & 18 & 4 & 4 & 5 & 5 \\
\hline
\end{tabular}


Continuation table 4

\begin{tabular}{|l|c|c|c|c|c|c|c|c|c|c|}
\hline $\begin{array}{l}\text { Oleksandr Dov- } \\
\text { zhenko Hlukhiv } \\
\begin{array}{l}\text { National Peda- } \\
\text { gogical University }\end{array}\end{array}$ & - & 1 & 1 & 2 & 1 & 1 & 1 & 4 & 6 & 5 \\
\hline $\begin{array}{l}\text { Ternopil Volody- } \\
\text { myr Hnatyuk } \\
\text { National Pedago- } \\
\text { gical University }\end{array}$ & - & - & 1 & 1 & 1 & - & 1 & 2 & 1 & 1 \\
\hline
\end{tabular}

In total, 69 higher education institutions - 54 universities, 9 institutes and 6 academies - have participated in the conference for 10 years. The conference was of interest to the representatives of such types of institutions as college (3), higher vocational school (1), gymnasium (1), lyceum (1), and secondary schools (11) as well.

The analysis of the geographical coverage showed that almost all regions of Ukraine - 24 regions out of 27 ones - participated in the conference for all ten years except the Autonomous Republic of Crimea, Kirovohrad Oblast and the city of Sevastopol. The city of Kyiv (541), Sumy (151), Cherkasy (71), Ternopil (49), Lviv (38), Poltava (38) and Khmelnitsky (20) oblasts participated most actively.

When presenting data, some of the indicators should be clarified. The number of the participants from Sumy oblast (151) combines data on participants from A. S. Makarenko Sumy State Pedagogical University and from Oleksandr Dovzhenko Hlukhiv National Pedagogical University. The data on Cherkasy oblast (71) primarily reflect the participation of the representatives of the Pavlo Tychyna Uman State Pedagogical University. The Poltava oblast (38) is represented by the educators of the Nizhyn Mykola Gogol State University.

The first foreign participant - a lecturer of the Wuhan Institute of Arts participated in the conference in 2011. However, the total percentage of the foreign participants is small compared to the Ukrainian researchers. This is partly explained by the format of the C\&IE during the first 7 years (2010-2016) - the All-Ukrainian seminar. Besides, the event mission - to unite the comparative educators of Ukraine to discuss the CE methodology and topical research areas for Ukraine - was primarily of interest to the Ukrainian researchers.

The transformation of the event format from the all-Ukrainian seminar to an international conference envisaged close cooperation with foreign partner institutions. The Institute for Educational Research of Romania was such partner in 2017 and the Scientific and Methodological Institution «The National Institute of Education» of the Ministry of Education of the Republic of Belarus - in 2018 and 2019. Such transformation increased the number of foreign participants.

Conclusions. Thus, the indices of participation at the individual level show that the conference has attracted considerable interest of a large number of researchers, despite its rather narrow professional orientation - the field of CE. The growth of such interest from year to year is evidenced by the data on the gradual increase in the number of the participants. Speaking about the individual profile of the participants it should be noted that the young researchers/faculty from higher 
education/research institutions constitute the majority of the participants. In fact, the conference has facilitated the formation of a generation of comparative educators who have enriched methodological approaches to CE research, initiated by the oldest CE unit in Ukraine - the Department of Comparative Education of the Institute of Pedagogy of the NAES of Ukraine (established in 1971, received its current name «Comparative Education Department» in 1991).

Although various institutions participated in the conference, the research centres/units and higher education institutions form the profile of the conference at the institutional level. It is in these institutions that CE studies are conducted, CE courses are taught, and professional journals are published. Activities in the field of CE stipulate the interest to discuss its developments, challenges and perspectives with colleagues. This is what the conference has been providing for a decade.

The positive dynamics of the participation of the regions of Ukraine in the conference should be noted. Gradually the conference attracted practically all regions of Ukraine. At the same time, there is a stable imbalance between the quantitative representations of the regions. The majority of the region-participants are the longstanding partners of the Department of Comparative Education of the Institute of Pedagogy, i.e. Cherkasy, Lviv, Sumy, Ternopil oblasts.

Based on generalization of data it is possible to speak about a number of accomplishments of the conference. First, the conference fulfilled its primary task - to unite the comparative educators of the NAES of Ukraine to discuss the CE methodlogy and topical for Ukraine research areas.

We can state that the young comparative educators from all over Ukraine make up the core of the C\&IE conference. The conference promoted their professional growth. By attending the conference, they gained new knowledge in CE research methodology. Beyond question it assisted them in writing dissertations in $\mathrm{CE}$, i.e., during the years of the conference, many of its participants received a PhD Degree in CE.

The support in the formation of regional communities of $\mathrm{CE}$ is another input of the C\&IE conference. Attendance of the conference by the representatives from different institutions of a region was the common practice. For example,

$\checkmark$ the Lviv Oblast was represented by the participants from Ivan Franko National University of Lviv, Lviv Polytechnic National University, Danylo Halytsky Lviv National Medical University;

$\checkmark$ the Sumy Oblast - by the participants from the A.S. Makarenko Sumy State Pedagogical University, Sumy National Agrarian University, Sumy In-service Teacher Training Institute, Sumy Dmitry Bortniansky High School of Art and Culture;

$\checkmark$ the Ternopil Oblast - by the participants from Ternopil Volodymyr Hnatyuk National Pedagogical University, Ternopil National Economic University, I. Horbachevsky Ternopil National Medical University.

Amalgamation of the comparative educators from all over Ukraine is to be viewed as a major accomplishment of the C\&IE conference. In fact, you can talk about the formation of the All-Ukrainian Comparative Educators' Community of Practice. Under the auspices of the C\&IE conference - the only professional conferen- 
ce on CE in Ukraine - the comparative educators gathered annually to discuss the experiences, challenges, perspectives of CE in Ukraine and worldwide, gain/ exchange new knowledge and advanced ideas. Therefore, based on the above, we can speak about the efficiency of the C\&IE conference.

Acknowledgement: the author would like to thank Mts. Liubov Antonenko, Master's student, Faculty of Psychology, Taras Shevchenko Kyiv National University for her help in data handling.

\section{References:}

Lokshyna, O. (2015). «Pedahohichna komparatyvistyka - 2015: rukh do bahatovymirnosti. Na prykladi doslidzhen, prezentovanykh u ramkakh naukovo-praktychnoho seminaru «Pedahohichna komparatyvistyka» uprodovzh 2010-2015 rokiv» [«Comparative Education - 2015: the movement to multidimensionality. On the example of studies presented in the framework of the seminar "Comparative Education» during 2010-2015»]. In Pedahohichna komparatyvistyka - 2015: yakisnyy vymir osvity zarubizhzhya ta ukrayins'kyy kontekst: materialy naukovo-praktychnoho seminaru (Kyiv, 11 chervnya 2015 r.) (pp. 1012) [Comparative Education - 2015: quality dimension of education abroad and the Ukrainian context: materials of the scientific and practical seminar]. Kyiv: Pedahohichna dumka.

Lokshyna, O. (2019). "Comparative \& International Education» conference»-ten years in the educational space. Education: Modern Discourses, 2, 190-191.

Porivnialno-pedahohichni studii - 2010. Prohrama naukovo-praktychnoho seminaru (Kyiv, 17 cheronia 2010 r.) (2010) [Studies in Comparative Education - 2010. Programme of the scientific and practical seminar (Kyiv, June 17, 2010)].]. Kyiv: TOV «Informatsiini systemy».

Pedahohichna komparatyvistyka - 2011. Prohrama naukovo-praktychnoho seminaru (Kyiv, 6 cheronia 2011 r.) (2011) [Comparative Education - 2011. Programme of the the scientific and practical seminar (Kyiv, June 6, 2011)].]. Kyiv: Instytut obdarovanoi dytyny.

Pedahohichna komparatyvistyka - 2012: aspekt obdarovanosti (transformatsiyi v osviti zarubizhzhya ta ukrayins'kyy kontekst). Prohrama naukovo-praktychnoho seminaru (Kyiv, 11 cheronia 2012 r.) (2012) [Comparative Education - 2012: Aspect of Giftedness (transformations of education abroad and the Ukrainian context). Programme of the scientific and practical seminar (Kyiv, June 11, 2012)]. ]. Kyiv: TOV «Informatsiyni systemy».

Pedahohichna komparatyvistyka - 2013: transformatsiyi $v$ osviti zarubizhzhya ta ukrayins'kyy kontekst.: Prohrama naukovo-praktychnoho seminaru (Kyiv, 10 cheronya 2013 r.) (2013) [Comparative Education - 2013: transformations in education abroad and the Ukrainian context. Programme of the scientific and practical seminar (Kyiv, June 10, 2013)].]. Kyiv: Pedahohichna dumka.

Pedahohichna komparatyvistyka - 2014: yakisnyy vymir osvity zarubizhzhya ta ukrayins'kyy kontekst. Prohrama naukovo-praktychnoho seminaru (Kyiv, 5 cheronia 2014 r.) (2014) [Comparative Education - 2014: quality dimension of education abroad and the Ukrainian context. Programme of scientific and practical seminar (Kyiv, June 5, 2014)]. ]. Kyiv: Pedahohichna dumka.

Pedahohichna komparatyvistyka - 2015: yakisnyy vymir osvity zarubizhzhya ta ukrayins'kyy kontekst. Prohrama naukovo-praktychnoho seminaru (Kyiv, 11 chervnya 2015 r.) [Comparative Education - 2015: quality dimension of education abroad and the Ukrainian context. Programme of scientific and practical seminar]. Kyiv: Pedahohichna dumka.

Pedahohichna komparatyvistyka - 2016: osvitni reformy ta innovatsii u hlobalizovanomu sviti. Prohrama naukovo-praktychnoho seminaru (Kyiv, 6 chervnya 2016 r.) [Comparative Education - 2016: education reforms and innovations in the globalized world. Programme of scientific and practical seminar]. Kyiv: Pedahohichna dumka.

Pedahohichna komparatyvistyka - 2016: osvitni reformy ta innovatsii u hlobalizovanomu sviti. Prohrama naukovo-praktychnoho seminaru (Kyiv, 6 chervnya 2016 r.) [Comparative Education - 2016: education reforms and innovations in the globalized world. Programme of scientific and practical seminar (Kyiv, June 6, 2016)]. Kyiv: Pedahohichna dumka. 
Pedahohichna komparatyvistyka i mizhnarodna osvita - 2017: osvitni transformatsii u konteksti yevropeiskoi intehratsii i hlobalizatsii. Prohrama I Mizhnarodnoi naukovo-praktychnoi konferentsii (Kyiv, 15-16 cheronia 2017 r.) [Comparative and International Education - 2017: education transformations under European integration and globalization. Programme of the $1^{\text {st }}$ scientific and practical conference (Kyiv, June 15-16, 2017)]. Kyiv: Pedahohichna dumka.

Pedahohichna komparatyvistyka i mizhnarodna osvita - 2018: transformatsii ta innovatsii vosviti u hlobalizovanomu sviti. Prohrama II Mizhnarodnoi naukovo-praktychnoi konferentsii 7-8 chervnia 2018 r. (Kyiv, 7-8 cheronia 2018 r.) [Comparative and International Education - 2018: transformations and innovations in education in the globilised world. Programme of the $2^{\text {nd }}$ scientific and practical conference (Kyiv, June 7-8, 2018)]. Kyiv: Pedahohichna dumka.

Pedahohichna komparatyvistyka i mizhnarodna osvita - 2019: internatsionalizatsiia ta intehratsiia $v$ osviti v umovakh hlobalizatsii. Prohrama III Mizhnarodnoi naukovo-praktychnoi konferentsii 30 travnia 2019 roku. (Kyiv, 30 travnia 2019 r.) [Comparative and International Education - 2019: internatiolisation and integration in education under globalisation. Programme of the $3^{\text {rd }}$ scientific and practical conference (Kyiv, May 30, 2019)]. Kyiv: Pedahohichna dumka. 